
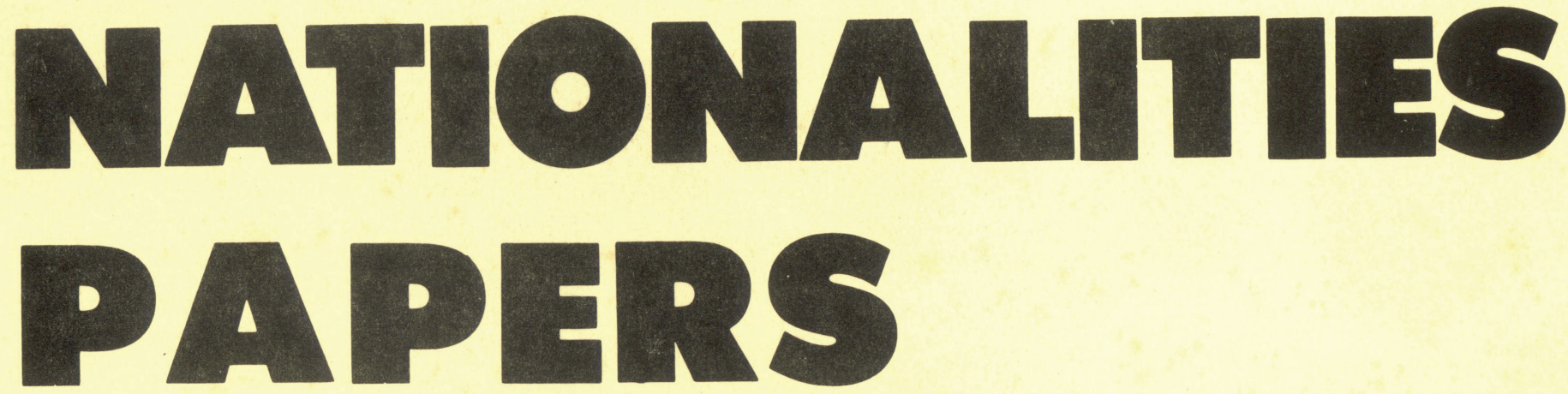

\title{
THE ASSOCIATION FOR THE
} STUDY OF THE NATIONALITIES (USSR AND EAST EUROPE) FALL, 1975 
NATIONALITIES PAPERS, sponsored by the Association for Study of the Nationalities (USSR and East Europe), invites the submission of articles, papers, and book reviews relating to the non-Russian nationalities of the USSR and national minorities of the East European countries in the fields of social sciences and humanities.

Articles should be submitted to Stephan M. Horak, Editor, 216D Coleman Hall, Eastern Illinois University, Charleston, Illinois 61920, and should follow the Library of Congress transliteration system. Books for review and book reviews should be sent to Andrew Ezergailis, Associate Editor, Department of History, Ithaca College, Ithaca, New York 14850.

Application for membership in the Association and subscription to the NATIONALITIES PAPERS, semi-annual, should be sent to Andris Skreija, Managing Editor and Secretary Treasurer, Department of Sociology, University of Nebraska at Omaha, Omaha, Nebraska 68101.

Effective January 1976, annual dues are $\$ 6.00$ per year (\$10.00 for two years) and include subscription to the NATIONALITIES PAPERS. The rate for library and institutional subscriptions is $\$ 8.00$ per year. Back volumes are available at $\$ 3.00$ per issue.

This issue contains two papers, with introduction and comments, that were delivered at the Seventh National Convention of the AAASS at Atlanta, Georgia, on October 10, 1975, in a session sponsored by the ASN. A timely article by Andrew Ezergailis on nationalism complements the general theme of the session.

Due to financial limitations it was decided to discontinue the publication of the Newsbox. In its place, NATIONALITIES PAPERS, will carry a special section, "News of the Association," beginning with Volume IV, No. 1 . 
The Association for the Study of the Nationalities (USSR and East Europe)

Vol. III, No. 2

Fall 1975

PROBLEMS OF PERIODIZATION AND TERMINOLOGY IN THE HISTORIES

OF BEIORUSSIANS AND UKRATNIANS

Introduction ......................... 1 Lowell Tillett

Problems of Periodization and Terminology in Ukrainian Historiography. 5 Stephan M. Horak

Problems in Terminology and in the Periodization of Belorussian History 25 Jan Zaprudnik

Commentary on Papers by Professors Horak and Zaprudnik . . . . . . . 46 Herbert J. Ellison

Comments on Periodization and Terminology in Byeloruthenian and

Ukrainian Histories . . . . . . . . . . . . . . . 50 Lubamyr R. Wynar

Nationalism in World Politics and History . . . . . . . . . 60 Andrew Ezergailis

Reviews . . . . . . . . . . . . . . . . . . . 89

Joseph S. Roucek

Eastern Europe: A Geography of the Comecon Countries, Mellor

A Psychohistory of Zionism, Gonen

Radio and Television Broadcasting in Eastern Europe, Paulu

Announcing: New Titles . . . . . . . . . . . . . . 93

Publications Received . . . . . . . . . . . . . . . 94

Statements or opinions published in NATIONALITIES PAPERS do not necessarily reflect the view of the Association or the Editors. 
HERBERT J . ELLISON

ANDREW EZERGAILIS

STEPHAN M. HORAK

LOWELL TILLETT

LUBOMYR R. WYNAR

JAN ZAPRUDNIK
Professor of History and Director of the Institute for Comparative and Area Studies, University of Washington

Professor of History, Ithaca College

Professor of History, Eastern Illinois University; Chairman of the ASN.

Professor of History, Wake Forest University

Professor of Library Science, Kent State University; Editor of Ukrains'kyi istoryk.

Assistant Professor of History, Queens College; Editor of Facts on Byelorussia. 